\title{
CONFERENCE CHEVREUL Nutrition research: the industrial approach
}

Oléagineux, Corps Gras, Lipides. Volume 7, Numéro 1, 74-6, Janvier - Février 2000, Dossier : actes des Journées Chevreul "Corps gras, nutrition et santé, questions d'actualité" (Bordeaux, Pessac)

Auteur(s) : Onno KORVER, Unilever Research, Vlaardingen Vijverwg 46, 3062 JP Rotterdam, The Netherlands.

Author(s) : Onno KORVER

Résumé : Mettre sur le marché des produits « santé » d'une façon responsable nécessite un dossier scientifique supportant les allégations nutritionnelles qui accompagnent le produit. Il est aussi nécessaire d'expliquer ces messages au consommateur, parce qu'il ne lui est pas possible de voir directement si le produit sert la santé et à quel niveau. Par expérience, l'industrie sait qu'il faut préparer la communication vers le consommateur par un dialogue avec le monde scientifique et un programme d'information pour les professionnels de santé, comme les médecins, les diététiciens et les journalistes scientifiques. Ce processus exige une crédibilité scientifique élevée de la part de la compagnie introduisant le produit. La médaille Chevreul que l'Association française des corps gras a décidé de me remettre montre que le groupe de recherche nutritionnel d'Unilever est considéré comme un groupe dont la tradition est véritablement scientifique. Pour cette raison, l'allocation de la médaille Chevreul est pour moi un honneur ainsi que pour tous mes collègues du Centre de nutrition d'Unilever. Pour illustrer les principes indiqués plus haut, j'ai choisi l'exemple du développement de margarines "santé du cœur ". Ces margarines ont une histoire de plus de 35 ans et ont toujours suivi le consensus scientifique. Au début, l'hypothèse supportant ces produits était l'hypothèse lipidique, indiquant l'importance de la composition en acides gras sur le taux de cholestérol sanguin. L'acide linoléique était établi dans les années suivantes comme l'ingrédient actif pour diminuer le cholestérol et ce rôle fut la base de notre communication pour les décennies suivantes. Depuis 1980, l'importance de la vitamine E pour la santé du cœur se manifestait. La contribution importante des margarines à taux élevé en acide linoléique (huile de tournesol) devenait un thème suivant de la communication. Récemment, on a réalisé que les acides gras n-3 (l'acide linolénique) avaient aussi un rôle très important à jouer à côté des acides n-6 (I'acide linoléique). Je souhaiterais vous présenter les résultats scientifiques publiés récemment : les études épidémiologiques et les études d'intervention avec des volontaires humains. Les résultats montrent que l'acide linolénique pourrait jouer un rôle important dans les processus thrombotiques. Si cela est confirmé, il faudrait envisager de l'introduire dans tous nos produits. Pour confirmer la situation scientifique, Unilever invitait quinze experts du monde entier à une réunion pour discuter les questions scientifiques relevantes. Les résultats de cette discussion ont été publiés. Ils sont à la base de nos formulations de produits d'aujourd'hui. Un nouveau développement très récent est fondé sur l'effet très puissant des " phytostérols » sur le taux de cholestérol sanguin. Je veux vous démontrer les données scientifiques qui supportent leur efficacité. Ces produits, qui sont déjà sur le marché, font partie du développement appelé functional foods. II sera intéressant de considérer à la fin de cette intervention ce que functional foods signifie pour la recherche nutritionnelle industrielle. 
Summary : The goal of nutrition research in an industrial setting is the marketing of products. Since consumers cannot see from the product whether it is healthy, communication to the consumer about the nutritional and health values of the products is essential. Industrial nutrition research therefore has to provide the scientific dossier to underpin the claims and other communication on and around the product as well as the scientific basis for the communication. These two lines are illustrated in figure 1. For scientific audiences the steps to collect the scientific evidence are obvious: first screening for new ideas on the basis of scientific developments and business options, then identifying ingredients that can deliver the health benefit, followed by mechanistic and bioavailability studies and finally human intervention trials. The communication line is less obvious for most scientifically oriented audiences. Experience has shown that an information cascade has to be followed: during the execution of the research work close contact with academic experts (a true dialogue) is essential, when the research data are available information of a wide selection of health professionals (e.g. physicians, dieticians, science journalists) is taking place and only after this step communication to the consumer starts. The communication with the scientific experts (the first step of the cascade) obviously has to be in the hands of the nutrition research group of the industry involved. In Unilever this is the Unilever Nutrition Centre based in Vlaardingen in the Netherlands. Their role in the scientific dialogue is outlined in figure 2. The fact that the "Medaille Chevreul" has been awarded twice to members of the Unilever Nutrition Centre in the last two decades, illustrates that the UNC is considered to be a group with a truly scientific tradition.

Mots-clés : margarine, linoléiacid, vitamin $E$, fatty acids $n-3$, phytosterols.

\section{ARTICLE}

\section{Introduction}

The goal of nutrition research in an industrial setting is the marketing of products. Since consumers cannot see from the product whether it is healthy, communication to the consumer about the nutritional and health values of the products is essential. Industrial nutrition research therefore has to provide the scientific dossier to underpin the claims and other communication on and around the product as well as the scientific basis for the communication. These two lines are illustrated in figure 1 .

For scientific audiences the steps to collect the scientific evidence are obvious: first screening for new ideas on the basis of scientific developments and business options, then identifying ingredients that can deliver the health benefit, followed by mechanistic and bioavailability studies and finally human intervention trials.

The communication line is less obvious for most scientifically oriented audiences. Experience has shown that an information cascade has to be followed: during the execution of the research work close contact with academic experts (a true dialogue) is essential, when the research data are available information of a wide selection of health professionals (e.g. physicians, dieticians, science journalists) is taking place and only after this step communication to the consumer starts.

The communication with the scientific experts (the first step of the cascade) obviously has to be in the hands of the nutrition research group of the industry involved. In Unilever this is the Unilever 
Nutrition Centre based in Vlaardingen in the Netherlands. Their role in the scientific dialogue is outlined in figure 2. The fact that the "Medaille Chevreul" has been awarded twice to members of the Unilever Nutrition Centre in the last two decades, illustrates that the UNC is considered to be a group with a truly scientific tradition.

\section{Illustration of the process: the history of "Heart-Health" margarines}

Margarines with health claims related to heart health have been on the market since the early sixties. They still exist and are a good example of a product that has kept up with the scientific developments in the lipid nutrition field. It is therefore of interest to discuss the four stages (the lipid hypothesis, vitamin E, n-3 fatty acids and phytosterols) of the scientific development that have been used in the communication as an illustration of the industrial approach.

\section{The lipid hypothesis}

The work of Keys in the fifties came to the conclusion that the dietary fat composition is an important determinator of blood lipid levels. The main conclusions at the time (saturated fat increases blood cholesterol, monounsaturated fat is "neutral" and polyunsaturated fat decreases blood cholesterol) remain valid until today. Although subsequent research has refined the data (especially the effects of individual fatty acids have been intensively researched) consumer communication has always been based on the simple lipid hypothesis as given in figure 3 .

The building of Heart-Health margarines from a speciality product sold in pharmacies into a mass market consumer product needed technology development (the tub instead of the wrapper made the marketing of soft spreads possible) as well as the confirmation of the link between lower blood cholesterol levels and reduced risk of cardiovascular disease [1].

\section{Vitamin $E$}

The realisation that vitamin $\mathrm{E}$, as an antioxidant, might protect LDL against oxidation [2] coupled to epidemiological findings that high doses of vitamin $E$ are protective against heart disease [3], increased the interest in this component of Heart-Health margarines. The fact that the oils rich in polyunsaturated fatty acids (e.g. sunflower oil) are also rich in vitamin E made the Heart-Health margarines one of the important contributors to vitamin $E$ intake. In the Netherlands margarines and oils contribute $46 \%$ to vitamin $E$ intake in 1994 [4].

Communication to the consumer was based on the scientific findings of vitamin $E$ benefits and the important contribution to the intake of vitamin $E$ that the sunflower oil based products made.

\section{n-3 fatty acids}

In talking about n-3 fatty acids it is good to differentiate between *-linolenic acid and the very long chain fatty acids EPA and DHA. Both classes decrease the risk of cardiovascular disease, but their effects are not identical: 
- *-linolenic acid lowers blood cholesterol levels and has been shown in epidemiological studies to decrease cardiovascular risk;

- the long chain $n-3$ fatty acids have been shown to reduce blood triglycerides.

For application in a product *-linolenic acid has advantages over the long chain n-3 fatty acids, because of its greater stability against oxidation. Pertinent publications about *-linolenic acid are the Lyon Heart study (a human intervention study with a high intake of *-linolenic acid [5]) and an epidemiological study in women [6].

The authors of the Lyon Heart study ascribe the positive effects to *-linolenic acid. However there are other differences in the diet that also may play a role. The epidemiological study indicates that there is an association between the intake of *-linolenic acid and a reduced risk of cardiovascular disease. It can, for obvious reasons, not prove a causal effect.

The new findings on $n-3$ fatty acids have given rise to discussions in various scientific groups about the role of the $n-3$ fatty acids versus that of the $n-6$ fatty acids. The following results of these discussions have been published.

*WHO/FAO $[7,8]$

The position of the WHO/FAO is that it is not possible to precisely define a ratio $n-3 / n-6$ on the basis of the scientific data available, but nevertheless an increase of the ratio in the diet to $1 / 10$ to $1 / 5$ was recommended.

* International Society for the Study of Fatty Acids and Lipids (ISSFAL) [9]

ISSFAL gives recommendations for the intake of $n-3$ fatty acids in absolute terms: $1 \%$ of energy as *linolenic acid and 0.35 of energy as long chain n-3 fatty acids. Surprisingly and not in line with other recommendations they recommend a linoleic acid intake of $2 \%$ of energy.

* European Academy of Nutritional Sciences (EANS) [10]

The international workshop of experts convened by EANS concluded that an increase of the intake of $\mathrm{n}-3$ fatty acids was required. They proposed an intake of $2 \mathrm{~g} /$ day for *-linolenic acid and $200 \mathrm{mg} /$ day for the long chain $n-3$ fatty acids. They also concluded that the use of the $n-3 / n-6$ ratio has little significance, because of the differences in the mechanisms of action of the $n-3$ and $n-6$ fatty acids.

The conclusions show a general support for an increased intake of $n-3$ fatty acids and specific recommendations for absolute intakes. The usefulness of the ratio $n-3 / n-6$ is under discussion. The recommendation to increase *-linolenic acid is reflected in the composition of today's Heart-Health margarines.

\section{Phytosterols}

To come to a new generation of Heart-Health margarines it is necessary to screen for new ingredients. Recently this has led to the introduction of phytosterols in margarines. These ingredients have a strong cholesterol reducing effect and bring the Heart-Health margarines clearly in the 
domain of Functional Foods. Functional Foods are defined as: Foods that are marketed with a health claim that is supported by scientific data.

The active component (ß-sitosterol) is esterified to improve the solubility and the bioavailability from fat matrices. The effect of different levels of phytosterol on the blood cholesterol level is shown in figure 4 [11].

In figure 4_Flora represents a linoleic acid based Heart-Health margarine. Normal consumption in a representative diet gives a blood cholesterol lowering of 3\% against a butter containing diet. The phytosterol enriched products lower blood cholesterol with approximately $10 \%$.

Functional Foods approaches with their significant influence on physiological functions may cause side effects. For phytosterols this is shown in figure 5. There is a dose dependent decrease of serum carotenoid levels. Health effects of carotenoids are suggested by the results of epidemiological studies, but causal relations between carotenoid intake or serum level and health have not been established. Experts in the field accept that a $10 \%$ reduction of serum carotenoid levels is within biological variation and acceptable.

\section{CONCLUSION}

From the above it is clear that scientific credibility is essential in order to be able to market "health". A product with health claims and communication has to follow the scientific consensus. New scientific developments have to be incorporated in a continuous way to remain up to date.

\section{REFERENCES}

1. (1984). The Lipid Research Clinics Coronary Primary Prevention Trial Results. JAMA, 251: 351-64.

2. DIPLOCK AT (1985). Vitamin E. In: Fat-soluble Vitamins - their biochemistry and applications, London : Heinemann: 154-244.

3. GAZIANO JM, HENNEKENS CH (1992). Vitamin in antioxidants and cardiovascular disease. Curr Opin Lipid, 3: 291-4.

4. TNO Nutrition Reseach, personal communication.

5. DE LORGERIL M, RENAUD S, MAMELLE N, SALEM P, MARTIN JL, MONJAUD I, GUIDOLLET J, TOUBOUL P, DELAYE J (1995). Mediterranean *-linolenic acid-rich diet in secondary prevention of coronary heart disease. Lancet, 343: 1454-9.

6. HU FB, STAMPFER MJ, MANSON JE, RIMM EB, WOLK A, COLDITZ GA, HENNEKENS CH, WILLETT WC (1999). Dietary intake of *-linolenic acid and risk of fatal ischemic heart disease among women. Am J Clin Nutr, 69: 890-7.

7. WHO/FAO (1994). Fats and Oils in Human Nutrition. FAO Food and Nutrition Paper, 57. 
8. WHO/FAO (1998). Preparation and use of Food-based Dietary Guidelines. WHO Technical Report Series, 880.

9. SIMOPOULOS AP, LEAF A, SALEM N (1999). Essentiality of and recommended dietry intakes for omega-6 and omega-3 fatty acids. Ann Nutr \& Metab, 43: 127-30.

10. DE DECKERE E, KORVER O, VERSCHUREN PM, KATAN MB (1998). Health aspects of fish and n-3 polyunsaturated fatty acids from plant and marine origin. Eur J Clin Nutr, 52: 749-53.

11. HENDRIKS HFJ, WESTSTRATE JA, VAN VLIET T, MEIJER GW (1997). Spreads enriched with three different levels of vegetable oil sterols and the degree of cholesterol lowering in normocholesterolemic and mildly hypercholesterolemic subject. Eur J Clin Nutr, 53: 319-27.

Illustrations

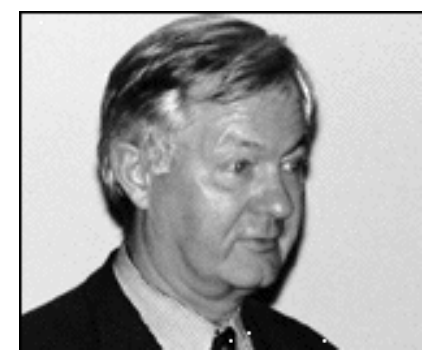

Onno Korver, Médaille Chevreu/Photo : O. Morin

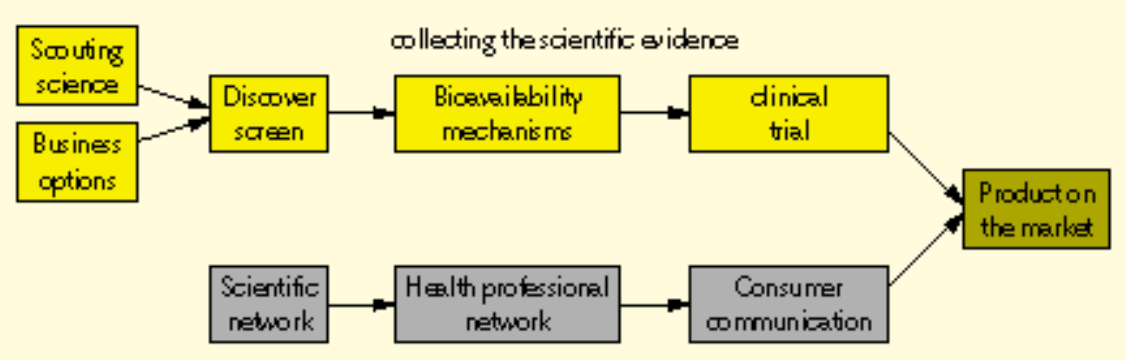

Figure 1. The elements of industrial nutrition research. 


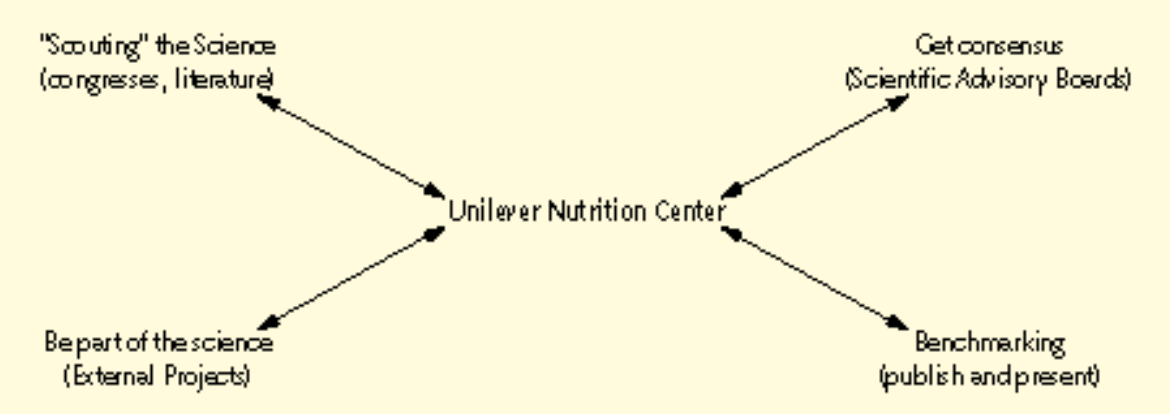

Figure 2. The scientific dialogue.

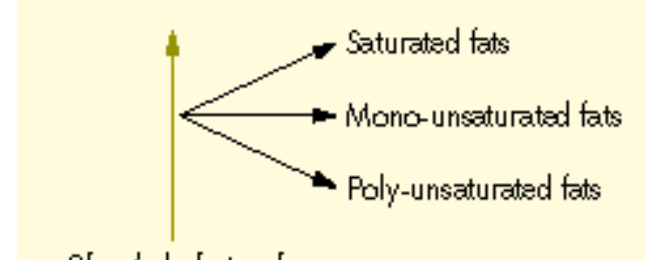

Blood choleterol

Figure 3. The relation between fatty acids and blood cholesterol.

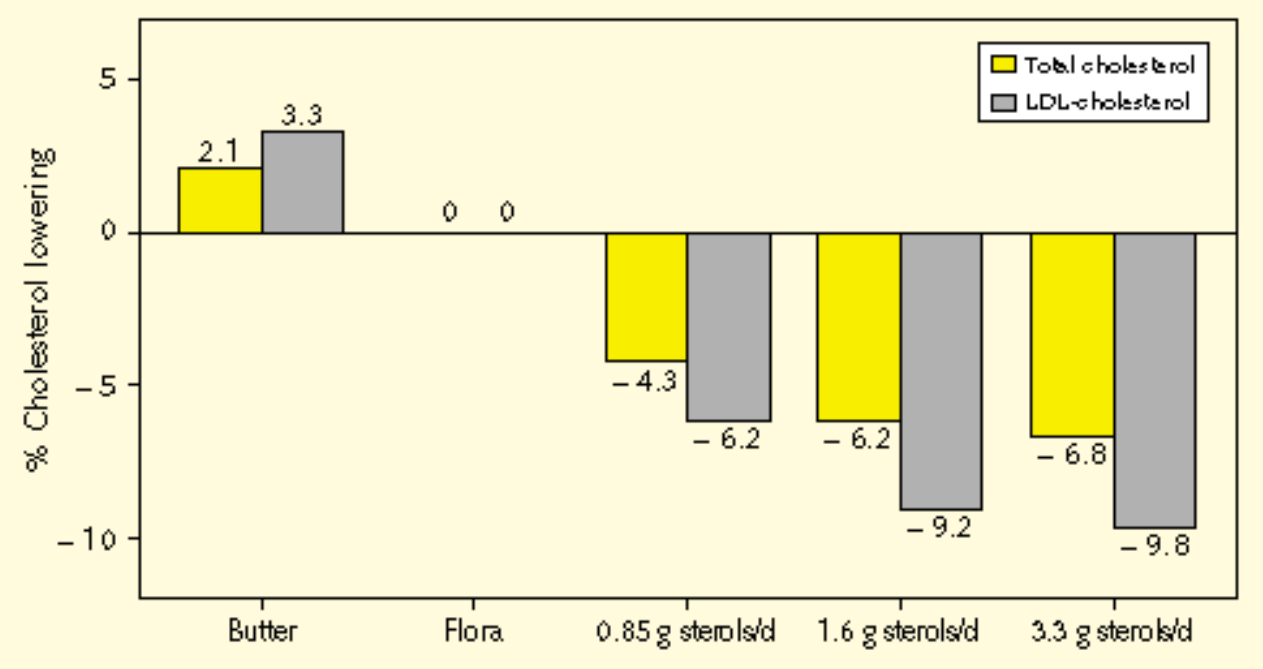

Figure 4. Efficacy of phytosterols for blood cholesterol lowering. 


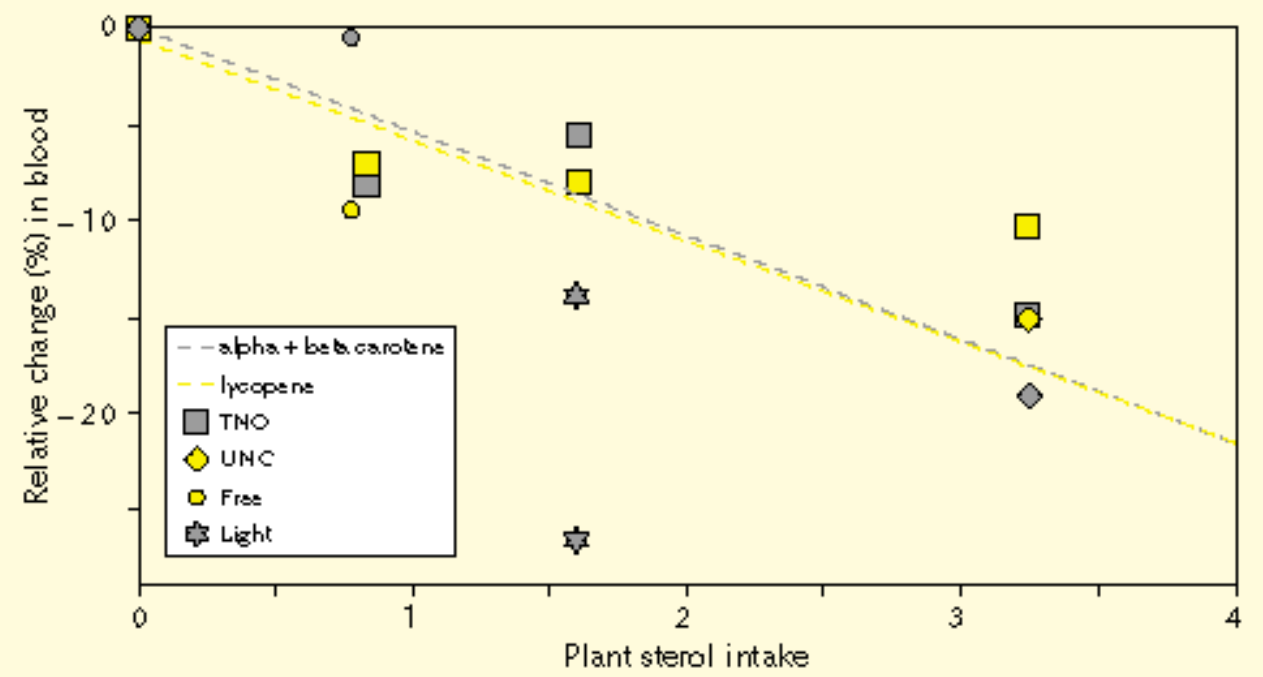

Figure 5. Influence of phytosterols on serum carotenoid levels. 